\title{
Accounting Education and Its Role in Light of Contemporary Trends in The Accounting Profession - An Applied Study
}

\author{
Jenan Abd AL-Abbas Al Dulamy¹, Ade Ghani Hamadi² \\ \{Jenan.aldulamy@atu.edu.iq1 ${ }^{\text {, ade.ghani@mustaqbal-college.edu.iq }}{ }^{2}$ \} \\ Babylon Technical Institute AL-Furat AL-Awsat Technical University1 \\ Al Mustaqbal University College 2
}

\begin{abstract}
The value of research is in examining the evolution of the accounting profession and determining how to address modern challenges to the accounting profession through education, training, and re-consolidation and reformulation. The internationalization of the work environment necessitates are the development of accounting education in line with those developments through the introduction of changes in accounting curriculum programmes and learning methods based on the use of a questionnaire that is devoted to the above purpose through a survey. The samples collected from university teaching staff have reached a set of conclusions, this includes the development in accounting has grown calls for the development of accounting education. For a profession, and the available possibilities for continuing education, it is critical to the profession's capacity to fulfil the tasks given to it, and from here, the trends in accounting education followed play a significant part in the profession's continuance and development.
\end{abstract}

Keywords: Accounting Education, Contemporary Trends In The Accounting Profession.

\section{$1 \quad$ Introduction}

The study dealt with a very important topic, which is accounting education, and because of its importance in advancing the accounting profession, as it works to increase the confidence of users of financial reports and investors in the quality of the outputs of those reports and their impact on decision-making. The efficiency of the outputs of the accounting system is related to its ability to issue financial statements of quality and transparency. High on the safety of accounting procedures, the efficiency of management and the appropriateness of its policies, and accounting education is the basis on which the scientific and professional staff are built capable of measuring and communicating economic events and the availability of appropriate 
information for decision-making, which requires the preparation and qualification of accountants and providing them with the knowledge and professional skills necessary to perform their role and this can only be achieved through Education, curriculum and skills. In light of the rapid and continuous changes in the business environment, on the one hand, globalization and the development of information and communication technology systems, which have become pressures, the accounting profession must respond to them to be up to the challenge imposed by the new circumstances and to enhance transparency, disclosure, and accountability, and ensure the quality of outputs. The accounting thought has witnessed development since the emergence of accounting in four stages, the first of which was the technical or professional stage, then the academic stage followed, then the third stage came to include the stage of information systems, and the fourth stage was the stage of social responsibility, which requires attention to accounting education to keep pace with contemporary trends in the profession Accounting. Based on the foregoing and to achieve the research objectives, the research was divided into several axes in addition to the introduction, as the first axis deals with the methodology of research and a review of some previous studies and the contributions made to the current research, and the second axis deals with a theoretical approach that includes accounting education and contemporary trends in accounting professions and accounting education and its role in qualifying accountants According to contemporary trends in the accounting profession, while the third axis dealt with presenting the results of the field study, while the fourth topic dealt with the most important conclusions and recommendations that have been reached.

\section{Research Methodology}

\subsection{Research problem}

Accounting is an integral part of the activities of economic units, and this is due to the importance of the services they provide, in addition to being the language of business and an information system that affects and is affected by the internal and external environment surrounding it, which is witnessing many rapid and continuous changes, so the quality of the accounting outputs Of great importance because it affects the decisions of users, and the quality of these outputs is mainly related to the efficiency of the accountant and the integrity of the accounting rules prepared on its basis, so the development of the accounting profession requires a focus on developing the capabilities of accountants, and higher education institutions are at the forefront of the responsible authorities for preparing qualified accountants who are available to them. The scientific and practical skills that enable them to practice the profession, and to meet the business needs of accounting, it was necessary to pay attention to accounting education and develop it to prepare accounting cadres capable of meeting the needs of the increasing demand for accounting arising from developments in the work environment, and the research problem in developing accounting education To meet the requirements of contemporary trends in the accounting profession, and work to provide graduates with skills and experiences a That required by the accounting labour market through accounting education.

\subsection{Objectives of the Research}

The research seeks to achieve the following objectives: 
1. Learn about the concept of accounting education, its importance, and the factors affecting it, as well as the obstacles facing accounting education.

2. Shedding light on contemporary trends in the accounting profession.

3. Identify the basic requirements to face the contemporary challenges of the accounting profession.

4. Presenting some recommendations that prepare the future ambition of the field of developing accounting education to be in line with contemporary trends in the accounting profession.

5. Survey the opinions of a sample of lectures in the accounting departments in Iraqi universities and their reflection on the development of accounting education.

\subsection{The importance of Research}

The importance of research lies in reviewing the developments that the accounting profession has undergone and how to face contemporary challenges to the accounting profession through education, training, and reformulating and reorganizing the accounting profession. The continuous development in the business sector has led to the emergence of new topics that require follow-up of accounting thought for Responding to global economic changes in the work environment, which requires the development of accounting education in line with these developments through the creation of changes in accounting curricula programs and learning methods, and an emphasis on integration between accounting education acquired field experience and the requirements of the labour market.

\section{$2.4 \quad$ Research Hypotheses}

The research seeks to achieve the following hypotheses:

1. The possibility of developing accounting education.

2. Recent trends have affected the accounting profession.

3. There are basic requirements to face the contemporary challenges of the accounting profession.

\subsection{Research Method}

The descriptive-analytical method was adopted to verify the research hypotheses, adopt the inductive method for scientific research, in addition to adopting the analytical and interpretive method for the results obtained from the sample opinions.

\section{$3 \quad$ Literature Review}

A local study: (Jabbar, 2015) Titled (The reality of accounting education in Iraq and its compatibility with international accounting education standards - an applied study of a sample of universities)]1] The study aimed to highlight the importance of the interaction of Iraqi universities that offer to account educational programs with the requirements of practicing the accounting profession. Through relying on accounting education programs that simulate the requirements of international accounting education standards, and in a way that is reflected in the development of the reality of the practice of the profession, the study used an analytical 
method using a questionnaire form, and the study reached the need to review the curricula and formulate them according to the requirements of the labour market in line with developments and provide training and education for lectures Undergraduates on methods of active education being the main pillar in accounting education programs, and for students' absorption to be according to the absorptive capacity of accounting departments.

An Arab study: A study (Medukh, 2014): Titled (The reality of the evolution of the accounting profession between the professional and technological qualification of accountants in companies operating in the Gaza Strip) )]2] This study aimed to demonstrate the impact of accounting and technological qualification on the actual reality of the accounting profession in the Gaza Strip, and also Demonstrating the importance of qualifying the accountant and his knowledge of information technology in facing the challenges that accompany the accounting profession, in addition to emphasizing the role of knowledge management and information technology in developing and improving accounting qualification. For this axis (67.4\%), through the companies' use of computers in accounting work, to achieve many advantages for them, and the results showed that obstacles are facing the process of developing the accounting profession in the Gaza Strip due to the lack of awareness of the company's owners about the accounting profession.

A Foreign Study: A Study (Bui \& Porter, 2010): Titled (The Expectation-Performance Gap in Accounting Education: An Exploratory Study) )]3]: This study came to explore and analyse the accounting education gap, since the mid-1980s, professional accounting bodies, employers and academics alike have expressed their regret at the failure of universities to equip accounting graduates with the competencies required for the modern business environment. Despite the introduction of changes to accounting education, the gap between the competencies that employers expect and that graduates possess remained, so the study aimed to determine the dimensions of the accounting education gap, and the research concluded with a proposal for a framework to reduce the expectation gap and the performance gap for accounting education in universities. New Zealand, after conducting interviews with students, academics, graduate trainees, and employers, while the study recommended the need for accounting departments in universities to update curricula and provide students with the necessary skills in line with the requirements of the modern business environment.

\section{The Contribution Made by The Current Research}

The previous studies agree that it was concerned with developing accounting education in universities and institutes and was adopted to achieve its goals on the questionnaire. As for the current study, it focused on developing accounting education in universities in line with contemporary trends in the accounting profession, which is supposed to be its first step in Developing education and improving outcomes to be able to meet the requirements of the labour market in the new work environment.

\section{Theoretical Entrance}




\subsection{Accounting Education}

Accounting education occupies a distinct position as it represents the reflective mirror of financial and economic performance and the backbone of economic units. The presence of accountants who possess the professional skills necessary to transform economic events into accurate information that meets the needs of their users is one of the indicators of the utmost care that accounting education receives in a way that ensures meeting the needs of the growing demand for Accountability, especially in light of the many and continuous changes in the sectors (financial, economic, ... and others) arising from the successive developments that surround it from all sides.

\section{A. The Concept of Accounting Education}

The definitions given by the writers and authors of the term Accounting Education have varied and varied. Accounting education is viewed as an organized process carried out by the responsible authorities, primarily universities, and through this process, the learner is provided with basic knowledge and the necessary scientific and practical capabilities that enable him. From the practice of the accounting profession 14], it becomes clear that the definition focused on providing the student (the learner) with knowledge and gaining the ability to practice accounting work, while Mudokh believes that accounting education is to provide the labour market needs of qualified and trained manpower Scientifically and practically, through which it can keep pace with the economic and social development plans that countries seek to achieve ]2], it is clear that the definition focuses on providing the labour market needs of graduates who have experience, skills, and knowledge in accounting and auditing work.

Based on the above, it is clear that accounting education refers to providing the labour market needs of qualified and trained manpower to keep pace with economic and social development plans, as well as harmony with the changes in the business environment.

The importance of accounting education stems from the importance of accounting and the benefits it can provide to the community within which it operates, and the importance of accounting education is represented in ]4]:

1. Contributes to the preparation and qualification of accounting staff, by providing them with various accounting knowledge.

2. Providing the accounting staff working in various economic units with the most important developments that accompany the profession.

3. Assist in determining the needs of the economic units in terms of programs and training courses, as well as solving the problems that these units face.

4. contribute to the development of the accounting profession by developing scientific curricula by modern developments.

\section{B. Factors Affecting Accounting Education}


Many factors affect the success of the accounting education program, which are reflected in the following ]5]:

1. Personal factors: These factors relate to the student's abilities, qualities, motivation, and effort.

2. Direct environmental factors: related to the immediate environment that has a clear impact on the student, and these factors include (family circumstances, financial circumstances, and study time).

3. The factors of the professional accounting education program: These include the nature of the program and the competencies that must be present to complete the program.

4. Work environment factors: They are related to the business environment and the role that a professional accountant aspires to in the field of accounting, and this includes (the public's expectations of the role that an aspiring professional accountant will play in the accounting profession).

\section{Obstacles to Accounting Education}

The education systems in most developing countries, including higher education in Iraq, face many challenges in our contemporary world that are characterized by accelerated scientific and technological progress, at a time when there are still many obstacles faced by these systems, the most prominent of which is the incompatibility of the absorptive capacity of higher education institutions with growth Population and the failure to keep pace with modern curricula and technologies in research and education, in addition to the limited interaction and partnership between higher education institutions with state departments and the private sector ]6]. Accounting education faces many obstacles, which are reflected in ]7]:

1. The study plans focus on the cognitive aspects more than on the technical aspects and experiences that are required for accounting students.

2. An outlook prevails in the accounting departments in universities indicating that research and education are two competing activities and not complementary activities and that continuing to establish this view will lead to bad consequences in the two activities, which makes accounting research not understood by professionals or that it does not serve them.

3. The extreme exaggeration in focusing on specialization in accounting departments, as studies have shown for the Accounting Standards Board of the Institute of Chartered Accountants in which 100 universities around the world that offer a basic program in accounting education have shown that the required credit hours range from 120-130 credit hours, and $25 \%$ Of them are related to non-accounting courses, i.e., they range from (30-35) credit hours.

4. The weak relationship between professionals and academics, as the relationship between the graduate and the university often breaks off after his graduation.

5. The methods of teaching accounting in universities are still traditional and do not keep pace with the spirit of the modern era in which technology prevails.

6. The accounting curriculum lacks the characteristic of suitability because it does not provide the graduate with the skills and expertise needed for the labour market. Accountants do it in practice, and what skills are there in practice ]8]. 


\subsection{Contemporary Trends in The Accounting Profession}

The development of accounting thought since the inception of accounting has witnessed four stages, the first of which was the technical or professional stage, then the academic stage followed, then the third stage came in which the information systems stage entered, and the fourth stage was the social responsibility stage. In the technical or professional stage, the doubleentry theory appeared in 1494. The accounting focused on recording notes and financial dealings in the records, and the accounts were organized, describing accounting at this stage as being an art and the American Accounting Association (AAA) defined the art of recording and classifying operations and events of a financial nature and interpreting the results of these operations and events.

And in the academic stage that began at the beginning of the nineteenth century, interest in accounting was described A science and social sciences for two main reasons. The first is the emergence of the Industrial Revolution and so on Its owner increased production and wealth, which prompted academics to lay down rules and foundations to preserve the capital and the distinction between income and capital, the second of which was the emergence of joint-stock companies and the resulting separation of management from the owners (owners of capital) to express the theory of agency, which led to the development of hypotheses consistent with the nature of The activities of the joint-stock companies, such as imposing the moral personality and imposing continuity, periodicity and harmony, as well as adopting generally accepted principles such as the interview, disclosure and recognition, and the stage of information systems, which is a tremendous development in accounting thought since the beginning of the twentieth century, has come as managerial accounting and quantitative and statistical methods have emerged to provide Data useful to management in the decision-making process.

At this stage, the definition of accounting came by the American Accounting Association (AAA) in 1971, describing it as a system for providing quantitative information on economic units and that this information is useful in terms of making and making decisions. Finally, the last stage of the development of the accounting thought came so that the focus at this stage is on the social responsibility of the economic units by measuring the cost and return and disclosing them to all the groups benefiting from the accounting information. The accounting definition of the American Accounting Association came in 1977 that accounting provides information that is useful in the decision-making process in a manner that leads to greater social welfare. Accordingly, the majority of contemporary studies have focused on the social, economic, and financial issues facing the various sectors. These studies have used information technology, methods and models that contribute to solving the problems faced by local and international economic units ]9].

\subsubsection{The Basic Requirements to Face Contemporary Challenges to The Accounting Profession}

The basic requirements are [10]:

1. Education: Rapidly reviewing the Curriculum education in the fields of accounting and management in universities to allow achieving goals of motivation, understanding, and 
application to meet the rapid development in the field of information technology and the increasing needs of management and other bodies outside the organization to additional reports that include useful information on areas that were not of interest. From before.

2. Training: To formulate integrated training programs for both professional accountants and management personnel to provide them with basic knowledge related to the effects of information technology on the nature of their work and the increased ability to meet the current needs of financial information.

3. Scientific Research: The fields of scientific research in the field of accounting and management in universities or elsewhere must be linked to the contemporary challenges facing the production and delivery of valuable financial information to users and find appropriate solutions for them.

4. Legislation: The speedy review of existing legislation that defines the patterns and size of the two information that must be provided in financial reports allows granting freedom to produce and provide more financial reports that provide valuable information to their users, especially since these two legislations represent a basic constraint in this aspect, as well as Its inflexibility to keep pace with the changes and formulate them at a time completely different from the contemporary time in terms of the existing challenges, including companies laws, capital law, law organizing the accounting profession and others.

5. Reorganizing and strengthening the accounting profession: by encouraging serious initiatives that are concerned with studying the existing problems and how to confront them and giving the profession an obligation force for members to adhere to the general charter for the profession.

\subsection{Accounting Education and Its Role in Qualifying Accountants According to Contemporary Trends in The Accounting Profession}

University institutions play an important role in preparing qualified accounting competencies possessing the scientific and applied skills that enable them to practice the accounting profession, through what they want to be in place, adapt and keep pace with competency-based education methods, there is no doubt that the successive and accelerating change and developments that accompanied the environment Business has a clear impact on the development of many sciences and professions, including accounting ]11], in addition to the studies that deal with the professional and academic development of accounting confirm the existence of two inherent characteristics, namely, as continuity indicates that there are many One of the elements of thought and application whose usefulness has been proven and stabilized with time and has become what is known as conventional wisdom. As for the characteristic of change, it embodies the dynamic nature of accountability and the ability to keep pace with the continuous development of the surrounding environmental factors ]12], As a result of the development in accounting, the demands for the development of accounting education increased, as the quality and development of the accounting profession is positively related to 
the quality of accounting education, the way in which accountants learn and the degree of development of the education they receive, the professional and educational requirements that must be met to join the profession, and the available opportunities to continue Education has a decisive importance for the profession in terms of its ability to advance the responsibilities entrusted to it, and from here the trends of accounting education followed have a decisive role in the continuation and development of the accounting profession around the world and in turn this affects the efficiency and growth of the national and global economy ]13]. Distinguish between two entries for accounting education:

1. The traditional approach: It is represented in the traditional method of teaching accounting or what is known as (indoctrination method), as accounting is studied according to this method without interconnection between the two sides (theoretical and applied), so it is unable to capture the professional requirements or application needs of the work environment.

2. The modern approach: It focuses on analytical abilities and skills in accounting, as it is concerned with skills in communication, information systems, decision-making, leadership, reliance on learning style, motivating students and urging them to search for science and accounting knowledge, and trying to find logical solutions to accounting problems, as well as It is about practicing practical cases and applications that do not have specific answers or typical solutions, which develops in them the faculty of thinking and brainstorming.

In the same context, there is a need to develop accounting skills in a way that can meet the required needs and according to the form that affects the increase in the interest of users, as the traditional image of the accountant as a number mill is no longer suitable for the profession, and the accountant is placed behind a table to collect huge columns of numbers to be presented to others from to make decisions, it is a non-vital issue that wastes effort and time, not to mention the mistakes that can occur. Computers and other types of modern technology and their tools have freed accountants from the tedious tasks of manual collection of financial information, so the future accountant is supposed to become more efficient and effective, taking upon himself a role The decision-maker and personal judgment through the experience and competence that he possessed in using his time for analysis and logical management regarding financial information, and he plays an active and effective role in the decision-making strategy within economic units ]14], which requires a shift from the traditional method in Education to the method of transferring the skills that professional organizations, most notably the International Federation of Accountants, called for the need to move according to this direction, that is, the skills that They are developed during the different educational stages that can benefit their acquired when moving to the stages of work, in addition to the practically developed skills that help accountants in transferring them to different work environments.

Within this perspective, there have been many opinions on how to develop the accounting profession. From the point of view of Scott 1970, the development of accounting information is required to meet the requirements of the internal and external users of accounting reports of institutions on the one hand, while the other side is represented in the set of legislations and laws that regulate the work of accounting, During the existence of a deliberate curriculum based on standards for accounting education. Others have argued that the development of the accounting profession by adopting the systems approach is done by changing the curricula of 
accounting education, provided that accounting is divided according to the following elements: The accounting function in the private sector, the local accounting profession, the accounting function in educational institutions, and the accounting in the government sector ]15].

Based on the above, we see that the development of the accounting profession due to its role in the planning process and economic development to achieve sustainable development, which requires setting a general framework for accounting that seeks to achieve those goals while taking into consideration the conditions of the economic and social business environment, as well as developing the elements of the accounting system by adopting Systems Entrance.

\section{$6 \quad$ Presenting the Results of the Field Study}

\subsection{Description of the Research Community and Research Sample}

The research community represents the teaching staff in the accounting departments in Baghdad and the governorates. As for the sample size, it reached (67) lectures, and they were chosen intentionally and deliberately and by $(60 \%)$ of the total community, Where the questionnaire is distributed to many teachers at the University of Baghdad, Al-Mustansiriya University, Al-Furat Al-Awsat Technical University, Babylon University, Future University College, Al-Hilla University College, Al-Qadisiyah University, Kufa University, Karbala University, Middle Technical University, Al-Muthanna University, in addition to publishing The link to the questionnaire in many accountants' groups and those who hold a science degree in accounting,

Table1 The forms distributed and returned from the research sample.

\begin{tabular}{|c|c|c|}
\hline Distributed forms & Returned forms & Percentage\% \\
\hline 67 & 60 & 90 \\
\hline
\end{tabular}

\section{A. Research tool}

The questionnaire was adopted as one of the tools adopted in collecting data. The questionnaire included two parts, the first of which was devoted to the demographic information of the research sample and the second part was concerned with the main axes of the research variables (accounting education, contemporary trends in the accounting profession) through three groups of questions.

\section{B. Statistical methods}

A set of statistical methods were used according to the (SPSS) program and the following: (percentage and frequencies to describe the research sample, the arithmetic mean, and the standard deviation), as well as the Cronbach's alpha test to find out the stability of the paragraphs of the questionnaire, and it turned out that the reliability coefficient was (0.8938), which is a good stability coefficient, and the Pearson correlation coefficient was adopted to calculate the internal consistency of the paragraphs of the questionnaire, and the correlation coefficients had a significant level of significance of (0.05), in addition to the value of (R) calculated greater 
than the tabular value of (R) at a degree of freedom (28) which is equal to (0.38) Accordingly, the paragraphs of the questionnaire are true to what they were measured for.

\section{Analysis of the Characteristics and Characteristics of the Research Sample}

The first part of the questionnaire contained a set of questions related to the demographic characteristics of the nature of the individuals responding to the questionnaire, and the aim of that was to give the impression that reinforces the confidence of the results that have been reached, and as in Table 2:

Table 2. Characteristics and characteristics of the research sample

\begin{tabular}{|l|l|l|}
\hline The paragraphs & Duplicates & Percentage \\
\hline Sex & & \\
\hline Males & 42 & $\% 70$ \\
\hline Female & 18 & $\% 30$ \\
\hline Total & 60 & $\% 100$ \\
\hline Qualification & & \\
\hline Master's degree or equivalent & 24 & $\% 40$ \\
\hline PhD or equivalent & 36 & $\% 60$ \\
\hline Total & 60 & $\% 100$ \\
\hline The scientific title & & \\
\hline assistant lecture & 9 & $\% 15$ \\
\hline Lecture & 15 & $\% 25$ \\
\hline Assistant Professor & 24 & $\% 40$ \\
\hline Professor & 12 & $\% 20$ \\
\hline Total & 60 & $\% 100$ \\
\hline
\end{tabular}

From the table, it becomes clear that the research sample constitutes a high percentage of males (70\%) and hold a doctorate by $(60 \%)$, and that the percentage of respondents holding the title of assistant professor with a percentage (40\%), followed by those holding the title of a lecture at a rate of $(25 \%)$, followed by a small assumption They hold the title of professor $(20 \%)$ and assistant lecture (15\%).

\subsection{The Results of the Field Study and Their Interpretation}

The second part of the questionnaire questions was devoted to a group of questions that were classified into three directions related to testing the research hypotheses:

Analysing and discussing the results of the research hypothesis test: To test research hypotheses, the questions were formulated for three sections, the first related to the reality of accounting education and included (12) paragraphs, while the second section included criteria for contemporary trends in the accounting profession and included (10) paragraphs, and the third section included the basic requirements to face Contemporary challenges to the accounting profession, knowing that the scale area was divided as a percentage for each degree as follows: (Totally $100 \%-80 \%$ agree, $79 \%-60 \%$ agree, neutral $59 \%-40 \%, 39 \%-20 \%$ disagree, $19 \%$ don't agree completely). 
Table 3. shows the results of the research sample responses for the first section of the questionnaire questions

\begin{tabular}{|c|c|c|c|c|}
\hline & The paragraphs & $\begin{array}{l}\text { Arithmetic } \\
\text { mean }\end{array}$ & $\begin{array}{l}\text { standard } \\
\text { deviation }\end{array}$ & percentage \\
\hline 1 & $\begin{array}{l}\text { There is a balance between the theoretical and applied } \\
\text { accounting education }\end{array}$ & 3.75 & 0.84 & $75.00 \%$ \\
\hline 2 & $\begin{array}{l}\text { The accounting applications course is insufficient to } \\
\text { qualify a graduate of the Accounting Department to join } \\
\text { the labour market }\end{array}$ & 3.80 & 0.61 & $76.00 \%$ \\
\hline 3 & The educational curricula are not updated periodically & 3.65 & 0.92 & $73.00 \%$ \\
\hline 4 & $\begin{array}{l}\text { There is no coordination between the economic and } \\
\text { educational institutions to exchange ideas and opinions } \\
\text { regarding the needs of the labour market and follow up } \\
\text { the accounting education process }\end{array}$ & 4.50 & 0.60 & $90.00 \%$ \\
\hline 5 & $\begin{array}{l}\text { Accounting education works to prepare outputs that are } \\
\text { compatible with the requirements of the analytical and } \\
\text { technical processes in accounting and auditing }\end{array}$ & 4.15 & 0.66 & $83.00 \%$ \\
\hline 6 & $\begin{array}{l}\text { Current teaching methods do not motivate students to } \\
\text { search for solutions to accounting problems using } \\
\text { several sources }\end{array}$ & 4.25 & 0.77 & $85.00 \%$ \\
\hline 7 & $\begin{array}{l}\text { Current training methods are not conducive to } \\
\text { leadership and teamwork development }\end{array}$ & 4.60 & 0.49 & $92.00 \%$ \\
\hline 8 & $\begin{array}{l}\text { Current educational methods are not conducive to } \\
\text { developing communication and communication skills } \\
\text { in the work environment }\end{array}$ & 4.25 & 0.63 & $85.00 \%$ \\
\hline 9 & $\begin{array}{l}\text { Accounting education helps in developing aspects of } \\
\text { accounting functions, including financial reporting, } \\
\text { administrative control, and auditing }\end{array}$ & 4.00 & 0.55 & $80.00 \%$ \\
\hline 10 & $\begin{array}{l}\text { The current educational curricula do not assist in the } \\
\text { graduate's acquisition of intellectual, technical, } \\
\text { personal, social, and organizational skills }\end{array}$ & 4.65 & 0.58 & $93.00 \%$ \\
\hline 11 & $\begin{array}{l}\text { Accounting education curricula help the graduate in } \\
\text { acquiring ethics and professional behaviour during the } \\
\text { education program }\end{array}$ & 4.35 & 0.58 & $87.00 \%$ \\
\hline 12 & $\begin{array}{l}\text { Accounting education contributes to improving } \\
\text { accounting and financing practices, procedures, and } \\
\text { financial policies }\end{array}$ & 4.35 & 0.66 & $87.00 \%$ \\
\hline & Total & 4.19 & 0.6575 & $\% 84$ \\
\hline
\end{tabular}

The first research hypothesis: Table 3 shows the results of the research sample responses for the first section of the questionnaire questions

It is evident from Table (3) that the arithmetic average of the research sample for the accounting education axis is (4.19) and represents (84\%) of the area of (for the quintet of Curt) used. That is, the first research hypothesis was accepted that accounting education in the local environment suffers from a weakness that requires its development, and the answers of the research sample can be analysed according to the following questionnaire questions:

1- The answers of the research sample regarding the balance between the theoretical and applied accounting education method amounted to $(75 \%)$ towards the agreement, and the value of the arithmetic mean was (3.75) in the same direction and by $(76 \%)$ and with an 
arithmetic average (3.8) the sample agreed that the subject of accounting applications is insufficient. To qualify a graduate of the Accounting Department to join the labour market.

Table 4. The results of the first section of the questionnaire

\begin{tabular}{|c|c|c|c|c|}
\hline & The paragraphs & $\begin{array}{l}\text { Arithmetic } \\
\text { mean }\end{array}$ & $\begin{array}{l}\text { Standard } \\
\text { deviation }\end{array}$ & $\begin{array}{l}\text { Percenta } \\
\text { ge }\end{array}$ \\
\hline 1 & $\begin{array}{l}\text { The technical or professional stage appeared when } \\
\text { accounting focused on recording notes and financial } \\
\text { dealings in the records and organizing accounts }\end{array}$ & 4.88 & 0.76 & $97.50 \%$ \\
\hline 2 & $\begin{array}{l}\text { The academic stage, which began at the beginning } \\
\text { of the nineteenth century, was concerned with } \\
\text { accounting as a science of social sciences }\end{array}$ & 4.92 & 0.80 & $98.50 \%$ \\
\hline 3 & $\begin{array}{l}\text { The emergence of the Industrial Revolution and its } \\
\text { accompanying increase in production and wealth } \\
\text { helped, prompting academics to lay down rules and } \\
\text { foundations for preserving capital and } \\
\text { differentiating between income and capital. }\end{array}$ & 4.90 & 0.78 & $98.00 \%$ \\
\hline 4 & $\begin{array}{l}\text { The emergence of joint-stock companies and the } \\
\text { resulting separation of management helped to } \\
\text { formulate assumptions consistent with the nature of } \\
\text { the activities of joint-stock companies }\end{array}$ & 4.94 & 0.84 & $99.00 \%$ \\
\hline 5 & $\begin{array}{l}\text { The stage of information systems, which is } \\
\text { considered a tremendous development in accounting } \\
\text { thought, as managerial accounting and quantitative } \\
\text { and statistical methods appeared to provide data that } \\
\text { benefit management in the decision-making process }\end{array}$ & 4.90 & 0.78 & $98.00 \%$ \\
\hline 6 & $\begin{array}{l}\text { The emergence of social responsibility for economic } \\
\text { units helped in conducting cost-benefit } \\
\text { measurement and disclosure for all groups } \\
\text { benefiting from accounting information. }\end{array}$ & 4.92 & 0.80 & $98.50 \%$ \\
\hline 7 & $\begin{array}{l}\text { The successive and accelerating changes and } \\
\text { developments that accompanied the business } \\
\text { environment have a clear impact on the development } \\
\text { of many sciences and professions, including } \\
\text { accounting. }\end{array}$ & 4.35 & 0.67 & $84.00 \%$ \\
\hline 8 & $\begin{array}{l}\text { Embody the dynamic nature of accounting and the } \\
\text { ability to keep pace with the continuous evolution of } \\
\text { the surrounding environmental factors }\end{array}$ & 4.25 & 0.63 & $87.00 \%$ \\
\hline 9 & $\begin{array}{l}\text { The quality and development of the accounting } \\
\text { profession positively correlates with the quality of } \\
\text { accounting education }\end{array}$ & 4.20 & 0.68 & $86.00 \%$ \\
\hline 10 & $\begin{array}{l}\text { The professional and academic development of } \\
\text { accounting confirms the existence of two } \\
\text { interrelated properties, continuity and change }\end{array}$ & 4.45 & 0.70 & $\mathbf{9 0 . 0 0 \%}$ \\
\hline & Total & 4.671 & 0.744 & $\% 94$ \\
\hline
\end{tabular}

2- The sample members believe that the current educational curricula are not updated at appropriate intervals and with an agreement rate (73\%) and an arithmetic average (3.65). Individuals of the sample agreed that there is no coordination between the economic and educational institutions in Iraq to exchange ideas and opinions regarding the needs of the labour market and follow-up The accounting education process, a percentage $(90 \%)$ and an arithmetic average (4.5), and a percentage (38\%) of the sample members agreed that accounting education works on preparing outputs that are compatible with the requirements of the analytical and technical processes in accounting and auditing. 
3-The research sample agreed that the current teaching methods do not motivate the student to search for solutions to accounting problems using several sources at a rate of $(85 \%)$ and with an arithmetic average (4.25). Developing the spirit of leadership and teamwork, with a mean of (4.6).

The second research hypothesis: Table (4) shows the results of the research sample responses regarding contemporary trends in the profession of financial accounting:

It is evident from Table (4) that the arithmetic means of the answers of the sample members amounted to $(4,671)$, which represents $(94 \%)$ of the Kurt five-year scale used, so the aforementioned percentage falls in the area of complete agreement (100-81\%), on contemporary trends in the profession Accounting, and according to that, the second research hypothesis is accepted.

The third research hypothesis: The third hypothesis: Table (5) shows the results of the responses of the research sample regarding the basic requirements to face contemporary challenges to the accounting profession, which states that:

Table 4. The results of the first section of the questionnaire

\begin{tabular}{|c|c|c|c|c|}
\hline & The paragraphs & $\begin{array}{l}\text { Arithmetic } \\
\text { mean }\end{array}$ & $\begin{array}{l}\text { Standard } \\
\text { deviation }\end{array}$ & $\begin{array}{l}\text { Percenta } \\
\text { ge }\end{array}$ \\
\hline 1 & $\begin{array}{l}\text { The technical or professional stage appeared when } \\
\text { accounting focused on recording notes and financial } \\
\text { dealings in the records and organizing accounts }\end{array}$ & 4.88 & 0.76 & $97.50 \%$ \\
\hline 2 & $\begin{array}{l}\text { The academic stage, which began at the beginning } \\
\text { of the nineteenth century, was concerned with } \\
\text { accounting as a science of social sciences }\end{array}$ & 4.92 & 0.80 & $98.50 \%$ \\
\hline 3 & $\begin{array}{l}\text { The emergence of the Industrial Revolution and its } \\
\text { accompanying increase in production and wealth } \\
\text { helped, prompting academics to lay down rules and } \\
\text { foundations for preserving capital and } \\
\text { differentiating between income and capital. }\end{array}$ & 4.90 & 0.78 & $98.00 \%$ \\
\hline 4 & $\begin{array}{l}\text { The emergence of joint-stock companies and the } \\
\text { resulting separation of management helped to } \\
\text { formulate assumptions consistent with the nature of } \\
\text { the activities of joint-stock companies }\end{array}$ & 4.94 & 0.84 & $99.00 \%$ \\
\hline 5 & $\begin{array}{l}\text { The stage of information systems, which is } \\
\text { considered a tremendous development in accounting } \\
\text { thought, as managerial accounting and quantitative } \\
\text { and statistical methods appeared to provide data that } \\
\text { benefit management in the decision-making process }\end{array}$ & 4.90 & 0.78 & $98.00 \%$ \\
\hline 6 & $\begin{array}{l}\text { The emergence of social responsibility for economic } \\
\text { units helped in conducting cost-benefit } \\
\text { measurement and disclosure for all groups } \\
\text { benefiting from accounting information. }\end{array}$ & 4.92 & 0.80 & $98.50 \%$ \\
\hline 7 & $\begin{array}{l}\text { The successive and accelerating changes and } \\
\text { developments that accompanied the business } \\
\text { environment have a clear impact on the development } \\
\text { of many sciences and professions, including } \\
\text { accounting. }\end{array}$ & 4.35 & 0.67 & $84.00 \%$ \\
\hline 8 & $\begin{array}{l}\text { Embody the dynamic nature of accounting and the } \\
\text { ability to keep pace with the continuous evolution of } \\
\text { the surrounding environmental factors }\end{array}$ & 4.25 & 0.63 & $87.00 \%$ \\
\hline 9 & $\begin{array}{l}\text { The quality and development of the accounting } \\
\text { profession positively correlates with the quality of } \\
\text { accounting education }\end{array}$ & 4.20 & 0.68 & $86.00 \%$ \\
\hline 10 & $\begin{array}{l}\text { The professional and academic development of } \\
\text { accounting confirms the existence of two } \\
\text { interrelated properties, continuity and change }\end{array}$ & 4.45 & 0.70 & $\mathbf{9 0 . 0 0 \%}$ \\
\hline & Total & 4.671 & 0.744 & $\% 94$ \\
\hline
\end{tabular}


Table 2. The results of the third section of the questionnaire

\begin{tabular}{|l|l|l|l|l|}
\hline & The paragraphs & $\begin{array}{l}\text { Arithmeti } \\
\text { c mean }\end{array}$ & $\begin{array}{l}\text { standard } \\
\text { deviation }\end{array}$ & percentage \\
\hline 1 & $\begin{array}{l}\text { Legislation: The speed of reviewing the existing } \\
\text { legislation that defines the patterns and volume of } \\
\text { information that must be provided in financial } \\
\text { reports allows granting the freedom to produce and } \\
\text { provide more financial reports that provide valuable } \\
\text { information to their users. }\end{array}$ & 4.25 & $85.50 \%$ \\
\hline 2 & $\begin{array}{l}\text { Training: To formulate integrated training programs } \\
\text { for both professional accountants and management } \\
\text { personnel to provide them with basic knowledge } \\
\text { related to the effects of information technology on } \\
\text { the nature of their work and what it requires to } \\
\text { increase the ability to meet the current needs of } \\
\text { financial information }\end{array}$ \\
\hline 3 & $\begin{array}{l}\text { Scientific Research: The fields of scientific research } \\
\text { in the field of accounting and management in } \\
\text { universities or elsewhere must be linked to the } \\
\text { contemporary challenges facing the process of } \\
\text { producing and communicating financial information }\end{array}$ & 4.40 & 0.67 & $91.00 \%$ \\
\hline 4 & $\begin{array}{l}\text { Reorganizing and strengthening the accounting } \\
\text { profession: by encouraging serious initiatives that } \\
\text { study the existing problems and how to face them }\end{array}$ & 4.50 & 0.59 & $88.00 \%$ \\
\hline 5 & $\begin{array}{l}\text { Education by reviewing the educational curriculum } \\
\text { in the fields of accounting and management in } \\
\text { universities to allow achieving goals of motivation, } \\
\text { understanding, and application to meet the rapid } \\
\text { development in the field of information technology } \\
\text { and the increasing needs of management }\end{array}$ & 4.70 & 0.46 & $94.00 \%$ \\
\hline Total & 4.48 & 0.572 & $\% 90$ \\
\hline
\end{tabular}

It is clear from Table (5) that the arithmetic average of the answers of the sample members is (4.48), which represents $(90 \%)$ of the area of the scale used because it is located in the area of complete agreement (100-81\%), that is, some obstacles prevent the development of accounting education in the environment. The fifth question in the axis related to the third hypothesis achieved the highest percentage of answers, with a percentage (94\%) and an arithmetic average (4.70), which indicates the individual respondents agree to education by reviewing the education curriculum in the fields of accounting and management in universities to allow achieving the goals of motivation, understanding, and application. To meet the rapid development in the field of information technology and the increasing needs of management, and accordingly, the third hypothesis is accepted.

\section{Conclusion}

The research came out with many conclusions, which are:

1. The importance of keeping pace with accounting with professional developments at the international level, through which accounting organizations seek to serve the community, 
by applying international accounting education standards that help to develop accounting education curricula, which is reflected in educational outputs and the preparation of efficient accounting cadres to practice the profession of accounting, which is reflected Positively on the financial statements of economic units.

2. A deficiency in accounting education curricula due to reliance on traditional methods of teaching, and the inconsistency of accounting education programs and curricula in terms of linking the theoretical and applied aspects by focusing on the theoretical side, as well as not keeping pace with technological developments.

3. As a result of the development in accounting, there have been increasing demands for the development of accounting education, as the quality and development of the accounting profession is positively related to the quality of accounting education, how accountants learn and the degree of development of the education they receive, the professional and educational requirements that must be met to join the profession, and what is available from Opportunities for continuing education are of crucial importance to the profession in terms of its ability to fulfil the responsibilities entrusted to it, and from here the trends of accounting education followed to have a decisive role in the continuation and development of the accounting profession.

4. The sample members agreed that the quality and development of the accounting profession positively correlates with the quality of accounting education.

There are three recommendations:

1. The importance of adopting the development of accounting education from an integrated perspective by developing educational curricula in accounting and contributing to the development of the profession by setting up a strategic framework for this development that takes into account the goals of accounting education and linking those goals with the needs of society and the requirements of practicing the accounting profession, and on the other hand linking the objectives Financial and moral requirements and needs, studying the causes of the gap between them, and suggesting accounting solutions.

2. Commitment to the continuous updating of accounting education curricula in line with the development of global accounting thought and contemporary trends of the accounting profession.

3. Developing the education philosophy to provide graduate students with broad accounting skills and knowledge, and to focus on developing analytical and innovative thinking.

\section{References}

[1] Jabbar, Nazem, The reality of accounting education in Iraq and its compatibility with international accounting education standards - an applied study of a sample of Iraqi universities -, Al-Muthanna Journal of Administrative and Economic Sciences,2015, pp. 110-131. 
[2] Madhoukh, Khayyam Muhammad Kamel, The Reality of the Development of the Accounting Profession between the Professional and Technological Qualification of Accountants in Companies Operating in the Gaza Strip, Master's Thesis in Accounting and Finance, Faculty of Commerce, Islamic University, Palestine, 2014.

[3] Bui \& Porter, The Expectation-Performance Gap in Accounting Education: An Exploratory Study, Accounting Education journals, No.19, 2010.

[4] Bou Azria, Hajira, The reality of accounting education in Algerian universities in light of the trend towards implementing International Financial Reporting Standards (IFRS) - a questionnaire study at the Jilali University in General, a master's thesis in financial and accounting sciences in the Faculty of Economic, Business and Management Sciences , Algeria, 2017.

[5] IAESB, International Accounting Education Standards Board, Development and Management of Written Examinations Based on the Practices of Selected IFAC Member Bodies, Information, 2014.

[6] Saad, Salma Mansour, The role of benchmarking in developing curricula for accounting departments in Iraqi universities, a research published in the Journal of Accounting and Financial Studies, Volume VII, Issue 20, 2012.

[7] Al-Ani, Safaa Ahmed Muhammad, Requirements for activating the quality of the university accounting education system in light of ISO standards, Al-Muhasibi Journal for Accounting and Auditing Sciences Quarterly scientific journal issued by the Syndicate of Accountants and Auditors, General Center Baghdad - Iraq, Volume 23, Issue 45, 2006.

[8] Srdar, Nujoud Abdulhadi Srdar, The Gap Between Learning And Teaching In Accounting Education: The Saudi Arabian Experience, The Thesis Is Submitted In Partial Fulfilment Of The Requirements For The Award Of The Degree Of Doctor Of Philosophy Of The University Of Portsmouth -UK, 2017.

[9] Al-Amiri, Saud Jaid Mashkour, Entrances to the Evolution of Accounting Thought, House of Approaches for Publishing, First Edition, Amman - Jordan , 2020.

[10] Al-Naghi, Mahmoud El-Sayed, Accounting Theory - Contemporary Introduction, Series of Accounting Knowledge 2, The Modern Library, Arab Republic of Egypt, 2017.

[11] Belkaoui, Ahmed Riahi Accounting theory ,2002.

[12] Al-Shirazi, Abbas Mahdi, Accounting Theory, Dhat Al-Salasil House, Kuwait ,1990.

[13] Al-Rubaie Jabbar Jassim, Factors of Building Technical Accounting Skills for Technical Education Authority Students, Technical Journal, Volume 20, Second Issue, BaghdadIraq ,2007.

[14] Al-Hubaity, Qasim Mohsen and Yahya, Ziad Hashem, "The Impact of Developments in Business Environment on Management Accounting in the Twenty-first Century", a research published in the Journal of Future Research, No. (13), 2006.

[15] Al-Mansouri, Jaber Hussein and Al-Mashkour, Emad Abdul Sattar, The extent of the contribution of the components of the accounting profession in raising the efficiency of accountants to rationalize investment decisions, Journal of Economic and Administrative Sciences - University of Karbala, Volume 1, Issue 3, 2012 ,pp. 48 -66. 